\title{
DEVELOPMENT OF GYMNASTICS LEARNING MEDIA BASED ANDROID
}

\author{
Fegie Rizkia Mulyana ${ }^{1}$, Ridwan Gumilar ${ }^{2}$, Novi Soraya ${ }^{3}$ \\ Universitas Siliwangi ${ }^{1,2,3}$ \\ fegierizkiamulyana@unsil.ac.id,ridwangumilar@unsil.ac.id,novisoraya@unsil.ac.id
}

\begin{abstract}
This study aims to develop and produce products in the form of gymnastics learning media based on android applications. This study uses research and development research methods with the ADDIE model (Analysis, Design, Development, Implementation, and Evaluations). The research carried out only reached the development or development stage, because this research only developed and produced an android application-based gymnastics learning media product called "GYMBASTECH" (Gymnastics Basic Techniques). The validation of this gymnastics learning media was carried out by three experts, namely floor exercise material experts, physical education learning media experts, and technical and informatics experts. The instruments used in this study were guidelines from interviews, questionnaires or validation questionnaires for 3 experts, and the system usability scale (SUS) to determine the usefulness of the media determined by the user as a product user. The result of the product obtained is that the percentage of floor exercise material experts is $80.77 \%$, physical education learning media experts are $81.25 \%$, and technical and informatics experts are $80.77 \%$. From the results of the three expert validations obtained an average of $82.51 \%$ this indicates that the gymnastics learning media "GYMBASTECH" is categorized as good and feasible to use in the learning process. The results of the response to the use of the gymnastics learning media product "GYMBASTECH" obtained an average of $58.44 \%$, so this product is categorized as good. Based on the results of the three experts, and the product usability test using the system usability scale, the product in the form of gymnastics learning media "GYMBASTECH" is said to be feasible and can be used in the gymnastics learning process. The next research plan will test the effectiveness of the product so that it can be seen the effect of "GYMBASTECH" media when used in the gymnastics learning process.
\end{abstract}

Keywords: Android, Learning Media, Gymnastics

Accepted: $07^{\text {th }}$ of January 2022
$\begin{aligned} & \text { Correspondence author: Fegie Rizkia Mulyana, Universitas Siliwangi. E-Mail: } \\ & \text { fegierizkiamulyana@unsil.ac.id }\end{aligned}$
DOI http://dx.doi.org/10.31851/hon.v5i1.6582 doi)

\section{(1) (2)}

Jurnal Halaman Olahraga Nusantara licensed under a Creative Commons Attribution-ShareAlike 4.0 International License

\section{INTRODUCTION}

Talking about education in the midst of a pandemic is a dilemma, but we as educators must be able to go through and conquer this challenge. A lecturer is required to be adaptive and innovative with the current pandemic conditions. As a 93 | Halaman Olahraga Nusantara copyright@Fegie Rizkia Mulyana 
result of the pandemic, problems emerged that were contrary to health protocols, so the Ministry of Education and Culture launched an emergency curriculum. A learning content that is adapted to the current situation and conditions. This situation cannot be separated from the role of digitalization to support online learning as well as what happens in universities. The change in the learning process from what was originally face-to-face or offline to now face-to-face or online. However, a lecturer must maintain the dignity of his educator, not forgetting what is the mandate of the candy or laws related to education. Learning outcomes in these courses must still be achieved in the cognitive, affective, and psychomotor domains. This achievement will not be separated from the strategies, methods, and media that lecturers implement in the e-learning process. According to (Mohammadi, Neda., Ghorbani \& Hamidi, 2011), e-learning is commonly referred to intentional use of networked information and communications technology in teaching and learning.

This statement is an ideal state that is dreamed of for e-learning users, empirical reality shows that there are still many teachers who teach by relying on themselves as the only media or learning resource (Mahnun, 2012). However, the reality in the field is that there are still other obstacles that occur in every online lecture, such as what happens in gymnastics learning lectures. Based on the results of interviews with several lecturers majoring in physical education, the obstacles experienced by all lecturers during online lectures were the difficulty of conveying information or materials to students, especially for practical materials. If it's just easy to convey, but if you want learning outcomes from all domains (cognitive, affective, and psychomotor) to be achieved, a lecturer must be innovative in designing or creating media and teaching materials that are relevant to the material presented. In addition, the obstacles that occur are caused by student limitations such as unstable network coverage in each area, eventually resulting in students going in and out of meetings on the zoom platform, the limitations of gadgets owned by students. Often, many student assignments do not arrive or students cannot collect assignments due to limited internal memory 
capacity to upload assignments and the operational system (OS) on the gadget. In addition to the obstacles that occur to students, the obstacles experienced by lecturers also vary in e-learning. The results of interviews with the teaching team of gymnastics learning courses at the Department of Physical Education, Siliwangi University, there are difficulties in delivering practical studies related to gymnastics learning content. Because gymnastics learning is a practical course with a weight of 0-2 credits, students should be equipped with knowledge related to gymnastics learning theory and students must be skilled in performing and helping movement techniques as well as teaching various basic floor gymnastics techniques. In line with these constraints (Nurseto, 2020) revealed that the obstacles that occur in learning gymnastics: (1) students have difficulty in carrying out specific floor gymnastics activities, such as fear, felt trauma, being overweight, (2) lack of innovation in teaching materials. learning that can overcome the problems encountered, (3) the use of Liquid Crystal Display (LCD) projectors which often jam. (4) android-based mobile learning opportunities. From some of the problems described above, they become the basis for evaluation and innovation for a lecturer in order to improve the quality and student learning outcomes.

Lecture material is deemed not to be sufficient and meaningful if it is only delivered through several platforms such as Zoom. The lack of basic technical video references that can represent a number of gymnastics learning lecture content is an obstacle in delivering lecture material. It should not be enough just to use an online platform or a learning management system (LMS) when the learning process takes place, but other media are needed that can help students learn both during lectures or outside of lecture hours in order to better understand and deliver learning material, so that the goal is achieved expected learning. E- learning offering flexibility means that learning can carried out anytime and anywhere through the device (Wiswanti, C., \& Belaga, 2020). So that the learning process can continue without reducing the essence of teaching and learning process itself. In interacting directly the media used can be in the form of send direct message 
(live chat), video call (video calls), voice calls (voice calls), and others. As for interacting with the time period certain (indirectly) can use forums/messages contained in the media used (Alaby, 2020).

Based on these shortcomings and constraints, the researcher concludes that to support lectures through e-learning, technology-based learning media that can be used offline are needed to reduce costs incurred by students. The media is designed based on an android application to be more familiar and practical in its use, as well as relevant to the needs of lecture content to help students in the learning process. Based on the educational and teaching problems that occurred during the pandemic, the researchers tried to develop an Android ApplicationBased Gymnastics Learning Media to support the learning process that cannot be separated from technology and information in the midst of a pandemic and in this Industrial Revolution Era.

Study of problems in the development of this android application-based gymnastics learning media, namely: (1) How to develop android-based gymnastics learning media? (2) What is the feasibility of android-based gymnastics learning media, so that it can be used in the learning process? The formulation of these problems became the basis for this research, as well as in the preparation of this monograph.

Previous research conducted (Titting, F., Hidayah, T., \& Pramono, 2017) entitled "Multimedia Development of Android-Based Floor Gymnastics Learning in Sports and Health Physical Education in High School". As for the results of the research, android-based floor gymnastics learning in physical education in high school, which can facilitate learning floor gymnastics for teachers and students. This study resulted in an Android-based learning media product for gymnastics in high school physical education that was effective and made it easier for teachers to help demonstrate floor exercise. In line with the research above, (Marvin, 2018) conducted a study entitled "Development of Physical Education-Pedia Applications on Android-Based Smartphones as Physical Education Learning Media for Class VII at SMPN 1 Bangkalan". Based on the feasibility of the results 


\section{HALAMAN Jendral A. Yani Street Lorong Gotong Royong 9/10 Ulu OLAHRAGA Palembang South Sumatera

of the Penjas-pedia application score with the predicate "Very Good" the researchers concluded that the use of smartphone media in supporting the physical education learning process activities at SMPN 1 Bangkalan is very effective and efficient and further suggestions to the next researcher are expected to be able to develop products Learning media applications that reach a wider audience are not limited to just one school, developing the next application product can reach more schools. Another research conducted by (Nurseto, 2020) entitled "Development of Android-Based DBL Floor Gymnastics Mobile Learning for Class VII SMP" is categorized as very feasible so that it can be used in the learning process.

Application products made in the research above, the material content only covers the scope of learning in junior high school (SMP) and high school (SMA), so that not all basic gymnastics techniques are conveyed because the application content is adapted to the respective school curriculum according to learning needs . The use of the application is only for teachers and students at the school. The advantages of the two studies above, both android-based floor gymnastics learning multimedia products, and Android-based Penjas-Pedia applications have both been tested for effectiveness.

The research and development of this android application-based gymnastics learning media, develops and produces android application-based gymnastics learning media products that can be used by teachers, lecturers, and even trainers in artistic gymnastics clubs. In other words, the android-based gymnastics learning media application product that is made can be implemented in educational gymnastics and achievement gymnastics. The content or technique of the material presented is very complete, including the basic techniques of gymnastics according to the name of the application, namely GYMBASTECH (Gymnastics Basic Techniques) which is useful for all people. This application can be used as a guide for coaches in the process of coaching early childhood athletes. In addition, the advantages of this very efficient product can be easily installed on all smartphones without the need to use a quota when using it. 
This study aims to produce a product in the form of an android application-based gymnastics learning media application that is useful for teachers and lecturers both theoretically and practically in improving the quality of learning, and becomes an option in determining learning media that is in accordance with the needs and characteristics of the material and students. In addition, the purpose of this research is to produce a gymnastics learning media application product that makes it easy for students or students to understand and learn the basic techniques of artistic gymnastics, as well as a guide for beginner trainers in practicing artistic gymnastics in their respective clubs.

Learning gymnastics that we know in schools such as elementary school, junior high school, high school, and college is clearly very different from gymnastics done in training clubs when viewed from the goals and outputs. Gymnastics according to (Werner, 2012) "gymnastic may be globally defined as any physical exercise on the floor or apparratus that promotes endurance, strength, flexibility, agility, coordination, and body control". Gymnastics in general can be defined as physical exercise on the floor or gymnastics using tools that increase endurance, strength, flexibility, agility, coordination, and body control. This is in line with the goals of physical education in schools, which are expressed (Bucher, 1979) "the goals to be achieved in physical education are organic aspects, namely aspects related to students' ability to develop muscle strength, cardiovascular endurance, and flexibility. Other goals such as neuromuscular aspects, interactive aspects, social aspects, and emotional aspects. Gymnastics learning that is carried out both at school and in college is called educational gymnastics. Educational gymnastics is a term that is applied to gymnastics learning activities both at school and at universities, whose main targets are directed at educational goals and learning objectives, namely the physical, mental, and social development of children. Teaching and learning activities carried out both in schools and in universities, in addition to requiring accuracy in choosing strategies, models, and learning methods also require a media used to deliver lecture material. Learning is an interactive process between teachers and students, involving multiple 
approaches using technology or learning media that will help solve factual problems in the classroom (Muhajir, 2017). In line with the theory above, (Arsyad, 2013) he media is a tool in the learning process both in the classroom and outside the classroom. Media in learning can be in the form of people, materials or events that can create learning conditions that allow students to get information related to lecture material. It can be concluded that the media is a tool to convey information or teaching materials in order to provide a stimulus and learning experience to students or students both used in the learning process or outside of learning.

The learning media created in this study is an android-based gymnastics learning media called gymbastech, the word gymbastech is an acronym for gymnastics basic techniques. This application displays thirteen basic floor gymnastics techniques including; (1) basic technique of forward roll, (2) basic technique of backward roll, (3) basic technique of diveroll, (4) basic technique of long backward roll, (5) basic technique of headstand, (6) basic technique of cartwheel, (7) technique basic round-off technique (8) basic handstand technique, (9) basic back extension/stutz technique, (10) basic neckspring technique, (11) basic headspring technique, (12) basic handspring technique, and (13) basic backhandspring technique. The media developed in this study provides information related to the understanding of basic techniques, descriptions of motion, common mistakes in performing movements, how to help movements, accompanied by video footage based on android applications. Android is the most popular operating system in the community because it has advantages such as the nature of open source which gives developers the freedom to create applications (Anggraeni, 2013). The initial goal of developing Android was to develop a sophisticated operating system intended for digital cameras. However, it was realized that the market for these devices was not large enough, and the development of Android was then shifted to the smartphone market to compete with Symbian and Windows Mobile (Welch, 2013). 
Android is an open source operating system and has code under the

Apache License that allows software to be freely modified and distributed by device makers, wireless operators, and application developers (Open Handset Alliance., 2012). In line with the above understanding, (Friesen, 2010) suggests Android is Google's software stack for mobile devices that includes an operating system and middleware. With the help of Java, the OS runs specially designed Java applications known as Android applications. Android applications are developed in the Java programming language using the Android software development kit (SDK). This SDK consists of a set of development tools (Overview, 2009). The process of making android applications is by writing script code that utilizes web languages, such as HTML, CSS and Javascript (Marhadini, 2017). How the Android OS works is a multitasking operating system and is considered an intelligent operating system, different from other operating systems (Okilanda et al., 2021).

GymBasTech gymnastics learning media (Gymnastics Basic Techniques) is an application developed by the author and a third party, namely hicaltech 87 . The content of the GymBasTech application is designed and contains descriptions of explanations and snippets related to videos of basic floor gymnastics techniques that go through the editing process to make it look attractive when users are using the application. The software used in making this android application is Basic 4 Android version 11.0 which is abbreviated as B4a V11. The programming language used is Visual Basic which is then migrated to Java by the software.

\section{METHOD}

The method used in this research is research and development. According to (Borg, W.R. and Gall, 2007) research and development is a process used to develop and validate educational products. In line with this understanding, (Sugiyono, 2011)says that research and development methods are research methods used to produce certain products, and test the effectiveness of these 
products. The main purpose of research and development is not to study or formulate theory, but to produce an effective product. Product development in this study uses the ADDIE model (Analyze, Design, Develop, Implement, and evaluate). The following concept of the ADDIE model can be seen in the image below:

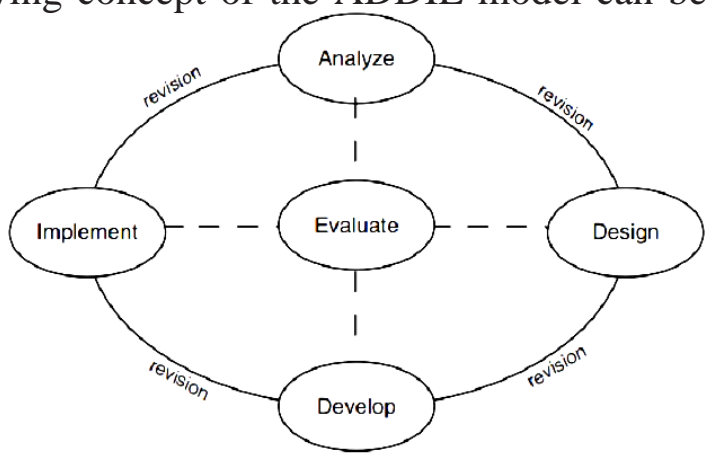

Figure 1. The ADDIE Concept (Branch, 2009)

According to (Mulyatiningsih, 2014) this model can be used for various forms of product development in learning activities such as models, learning strategies, learning methods, media and teaching materials. ADDIE development research model, the steps are considered more rational and more complete. This gymnastics learning media product was created and designed by researchers, with the aim of being able to be used as a tool for teachers and lecturers in delivering material and also as a learning resource for students. The stages in this research only reach the development stage, because this research aims to develop and produce valid android application-based gymnastics learning media products based on the assessment of three validators (floor exercise material experts, physical education learning media experts, and informatics experts) so that they can implemented in the online or offline learning process. The research steps that the author did using the ADDIE model, will be explained as follows;

1) Analysis, at this stage consists of analyzing problems that occur in the field, identifying deficiencies and obstacles that occur in the field, analyzing learning materials and media and other needs in the learning process. From this analysis, it can be concluded that the material to be delivered requires media assistance as a lecturer's tool in delivering material and the needs of students for independent study. By using an android application-based 
gymnastics learning media application, lecturers can provide theoretical and applicable explanations in the media.

2) Design, at this stage the lecturer does, namely: a) designing gymnastics learning media based on android applications; b) compiling material content, images and videos that are appropriate and appropriate to the material to be delivered), c) designing student response questionnaires to get feedback from the media, and designing validation sheets for media experts, informatics engineering experts and material experts.

3) Development, the result of the development stage is an android applicationbased gymnastics learning media application, this application consists of teaching material content such as technical descriptions, tutorials on how to do techniques, how to help techniques, and common mistakes related to motion tasks to be studied. This media contains pictures, videos, and other information related to gymnastics learning.

The instrument used in this study was in the form of a questionnaire or validation sheet given to three experts in floor exercise material, physical education learning media expert, and information technology expert to determine the validity and feasibility of gymnastics learning media. In addition to determining the feasibility of the product by experts, the products made are also tested using the System Usability Scale (SUS) questionnaire to determine the feasibility of using the product given to students as users of the media. The categories or criteria for determining media eligibility according to (Riduwan, 2011) can be seen in the table below,

Table 1. Media Feasibility, (Riduwan, 2011)

\begin{tabular}{ccc}
\hline No & Presentase & Keterangan \\
\hline 1 & $80 \%-100 \%$ & Good/Valid \\
2 & $60 \%-79,99 \%$ & Fairly Good / Fairly Valid \\
3 & $50 \%-59,99 \%$ & Not Good / Less Valid \\
4 & $0-49,99 \%$ & Not Good / (Replaced) \\
\hline
\end{tabular}


While the criteria for determining the feasibility of using the application using a questionnaire translated into Indonesian by (Sharfina \& Santoso, 2016)

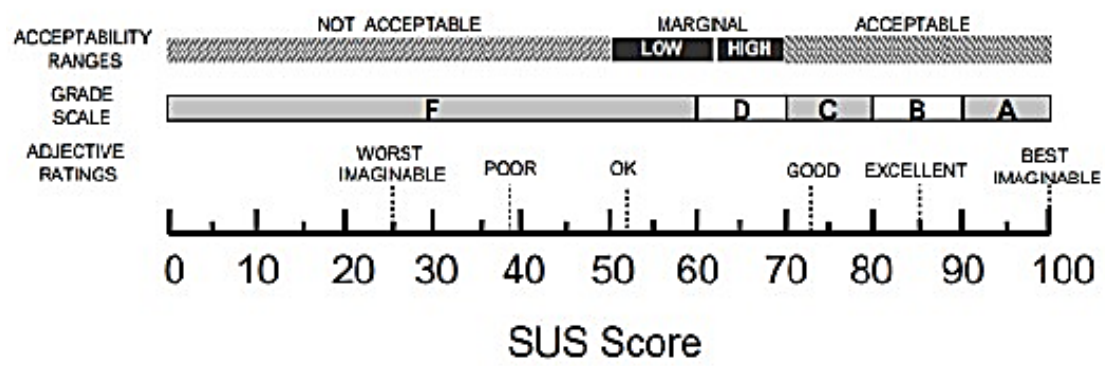

Figure 2. SUS Score Criteria (Sharfina \& Santoso, 2016)

Data collection techniques in this study were interviews and discussions, digging up information in the field, and distributing questionnaires. Data analysis is the compilation of data obtained from interviews, field notes, and documentation systematically, and concludes them into certain categories and describes them into units, synthesizes, arranges into patterns, chooses which ones are important to be studied so that they are easily understood by themselves. and other people (Sugiyono, 2011). The data analysis used in this study are: (1) Collecting all observational data in the form of field notes, interview notes, and discussion notes, (2) Conducting the first analysis to sort the data into categories; the first category is related to product improvement, the second category is related to the effectiveness of the product and the achievement of product objectives, (3) Conducting a second analysis in each category; the first related to the analysis carried out to find supporting data for product improvement, the second category of analysis was carried out to map the feasibility of the product and the achievement of the product objectives, (4) Carry out the synthesis process, namely processing the entire data to formulate the achievement of the final product using descriptive qualitative and quantitative descriptive analysis.

Qualitative descriptive analysis is used to display and process data in written form from research subjects as well as data from the reviews of experts (material experts, media experts, and informatics engineering experts) and the results of student trials. This data analysis technique is carried out by grouping 
information from qualitative data in the form of input, feedback, criticism, and suggestions for improvement contained in the questionnaire, then used to revise the product developed.

While quantitative descriptive analysis is "a method of data processing carried out by systematically compiling in the form of numbers and or percentages, regarding an object under study, in order to obtain general conclusions" (Agung, 2011), and (5) Making final conclusions . Concluding the results of data analysis and drawing conclusions from the revised results of teaching media products based on android applications.

\section{RESULT AND DISCUSSION}

The learning media product produced in this study is an android application-based gymnastics learning media called "GYMBASTECH" Gymnastics Basic Techniques". The purpose of developing this gymnastics learning media is to provide convenience for both lecturers, teachers or students in learning the basic materials and techniques of gymnastics. This application contains 13 basic gymnastic techniques which discuss the understanding of basic techniques, descriptions of motion or how to do basic techniques, and tips on how to help with basic gymnastics techniques.

In addition to text that users can read and understand, this application is equipped with complete videos of all the basic techniques presented including; (1) basic technique of forward roll, (2) basic technique of backward roll, (3) basic technique of diveroll, (4) basic technique of long backward roll, (5) basic technique of headstand, (6) basic technique of cartwheel, (7) basic technique of handstand , (8) basic technique of back extension/Stutz, (9) basic technique of neckspring, (10) basic technique of headspring, (11) basic technique of handspring, (12) basic technique of round-off, (13) basic technique of flic-flac/ backhandspring. 


\section{OLAHRAGA \\ Jendral A. Yani Street Lorong Gotong Royong 9/10 Ulu

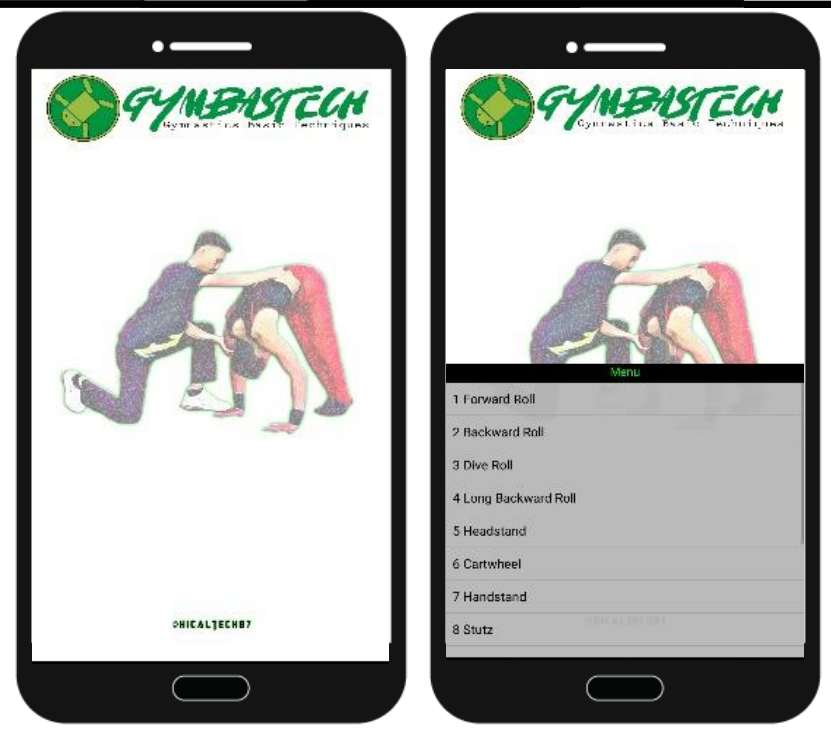

Figure 3. Main Page "GYMBASTECH”

This android application-based gymnastics learning media was designed and conceptualized by researchers and assisted by a second party, namely "hicaltech87" in translating into programming languages. The software used in making gymnastics learning media based on this android application is Basic 4 Android version 11.0 which is abbreviated as B4a V11. The programming language used is visual basic which is then imported into the Java language by the software. This software uses 2 coding parts, namely a module that functions as a manager of the command process to operate the display, and a designer that functions to create a menu page display, etc. The following is a picture of the B4A application,

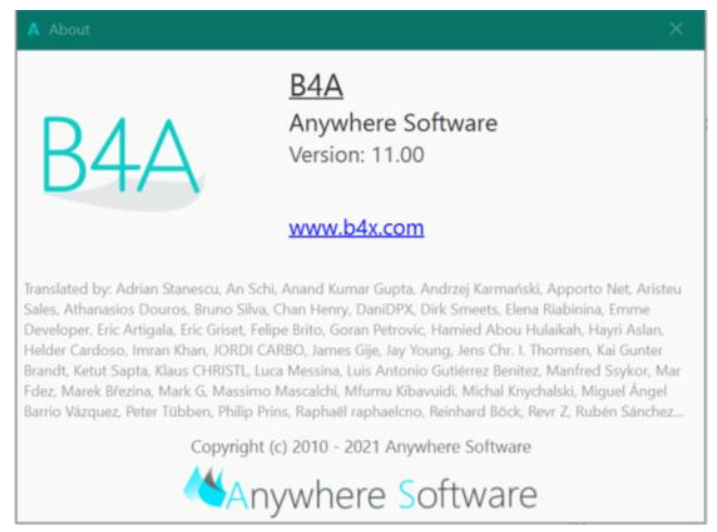

Figure 4. Software B4a V11 
The development of this android application-based gymnastics learning media uses the ADDIE learning media design model, namely Analysis, Design, Development, Implementation and Evaluation. The research carried out was only up to the Development stage, because the purpose of this research was only to develop and produce a valid android application-based gymnastics learning media to be implemented based on the assessment and input of 3 validators (material experts, media experts, and technical experts). informatics) and user or student responses. Based on the validation results from the three experts (material experts, media experts, and information technology experts) quantitative and qualitative data were obtained. The quantitative data obtained were then analyzed descriptively and reflected whether or not this android-based gymnastics learning media was appropriate, while the qualitative data obtained were further reduced and used as material for evaluation or revision of the products developed. The data analysis technique used in this research is descriptive analysis, namely by calculating the percentage value of the validation results. The greater the percentage score of the results of data analysis, the better the level of feasibility of the product being developed. The calculation formula is as follows,

$$
\text { Percentage }=\frac{\text { score earned }}{\text { maximum score }} \times 100
$$

The results of the validation of material experts related to the development of gymnastics learning media based on this android application were declared "Good/Valid" which resulted in a percentage of $80.77 \%$. As for the assessment indicators in the expert validation questionnaire include aspects of content and aspects of language. Suggestions from material expert validators are that this application is good, it just needs to be improved a little bit for the beginning of motion mechanics in the basic techniques of headstand, neckspring, and hedspring. In addition, this application needs to be further developed for some complex advanced basic techniques, so that it becomes a reference and guide for practitioners as well as academics. 


\section{HALAMAN}

Table 2. Material Expert Validation Results

\begin{tabular}{c|ccc}
\hline \multicolumn{1}{c}{ Dimension } & Indicator & Percentage & Result \\
\hline Material Expert & $\begin{array}{c}\text { Content aspect } \\
\text { Aspects of } \\
\text { language }\end{array}$ & $80,77 \%$ & Baik/Valid \\
\hline
\end{tabular}

The results of media expert validation related to the development of gymnastics learning media based on this android application were declared "Good/Valid", which resulted in a percentage of $81.25 \%$. The assessment indicators in the media expert validation questionnaire include according to the needs of the teacher, according to the needs of students, according to the material, according to learning objectives, student interests, and giving influence in learning. Suggestions from media expert validators are that the motion element needs to be improved to make it more detailed, and it is necessary to improve the image or video quality of this gymbastech application.

Table 3. Media Expert Validation Results

\begin{tabular}{|c|c|c|c|}
\hline Dimensi & Indikator & Percentage & Result \\
\hline $\begin{array}{l}\text { Media } \\
\text { Expert }\end{array}$ & $\begin{array}{l}\text { according to the needs of the teacher, } \\
\text { according to the needs of students, } \\
\text { according to the material, } \\
\text { according to learning objectives, } \\
\text { student interest, } \\
\text { give influence in learning, }\end{array}$ & $81,25 \%$ & Good/Valid \\
\hline
\end{tabular}

The results of the validation of informatics technicians related to the development of gymnastics learning media based on this android application were declared "Good/Valid" which resulted in a percentage of $82.50 \%$. The assessment indicators in the media expert validation questionnaire include aspects of appearance, aspects of convenience, and aspects of language. As for the advice of the validator of informatics engineering experts, for future application development, it should be filled with elements of the IMK concept so that users feel that this application is user-friendly. In addition, add a developer/copyright holder profile, as a self-identity in this gymbastech application. 
Table 4. Validation Results of Informatics Engineering Experts

\begin{tabular}{cccc}
\hline Dimension & Indicator & Percentage & Conversion \\
\hline $\begin{array}{c}\text { Informatics } \\
\text { Engineer }\end{array}$ & $\begin{array}{c}\text { Display aspect } \\
\text { Aspect of } \\
\text { convenience } \\
\text { Language aspect }\end{array}$ & $80,77 \%$ & Good/Valid \\
& & & \\
\hline
\end{tabular}

The average results from the validation of the three experts (material experts, media experts, and information technology experts) obtained a percentage of $82.51 \%$. This shows that the validation value of the android application-based gymnastics learning media product is in the range of $80 \%-100 \%$. According to the criteria for determining media eligibility according to (Riduwan, 2011) that the percentage of $80 \%-100 \%$ is declared good/valid. Then the android application-based gymnastics learning media is said to be feasible to use in the learning process.

Table 5. Average Validation Results of Experts

\begin{tabular}{l|ccc}
\hline \multicolumn{1}{c}{ Experts } & Percentage & Average & Appropriateness \\
\hline Material Expert & $80,77 \%$ & & \\
Media Expert & $81,25 \%$ & $82,51 \%$ & Good/Valid \\
Informatics Engineer & $80,77 \%$ & & \\
\hline
\end{tabular}

In addition to the validation results and input from the three experts (material experts, media experts, and informatics engineering experts), this android application-based gymnastics learning media is usefully assessed based on student responses using the usability of scale (SUS) system. System usability of scale (SUS) is a survey that aims to assess the usability of a product or service consisting of five positive statements and five negative statements. The results of the usability response of the android application-based gymnastics learning media product are described below, 
Table 6. Product Usability Response Results

\begin{tabular}{ccc}
\hline Subject & Average & Adjective Ratings \\
\hline $\mathbf{1 6}$ & $58,44 \%$ & Good \\
\hline
\end{tabular}

\section{CONCLUSION}

The results of this research and discussion are the production of an android application-based gymnastics learning media product called "GYMBASTECH" which is an acronym for Gymnastics Basic Techinques.

This application can be downloaded on google playstore with the application name "GymBasTech" or can be downloaded at the following link, https://play.google.com/store/apps/details?id=hicaltech87.gymnasticsbasictechniu e.GymBasTech.

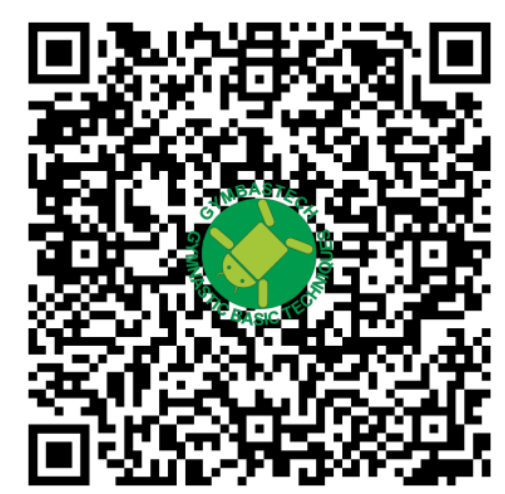

Figure 5. QR CODE GYMBASTECH

The validation results from the three experts (material experts, media experts, and information technology experts) are categorized as good/valid and declared worthy to be used in the gymnastics learning process with the average value of the three experts, which is $82.51 \%$. While the results of the product usability test using the usability scale (SUS) system obtained an average value of $58.44 \%$, thus this product is feasible and can be used in learning gymnastics both offline and online.

Some suggestions for further research or for other researchers, this product needs to be further developed both in terms of video or image quality and lighting, place background, and sound or audio. In addition, other researchers hope to be able to develop similar applications that discuss methods in training or teaching 
gymnastics. Showing systematics or steps how to teach or train easy movements

to complex movements. Because in the field there are still very few reference sources, either in the form of applications or in the form of books.

\section{REFERENCES}

Agung, A. A. G. (2011). Metode Penelitian Pendidikan: Suatu Pengantar. Fakultas Ilmu Pendidikan, Universitas Pendidikan Ganesha.

Alaby, M. A. (2020). Media Sosial Whatsapp Sebagai Media Pembelajaran Jarak Jauh Mata Kuliah Ilmu Sosial Budaya Dasar (ISBD). Ganaya: Jurnal Ilmu Sosial Dan Humaniora, 3(2), 273-289.

Anggraeni, R. D. \& R. K. (2013). Pengembangan Media Animasi Fisika Pada Materi Cahaya Dengan Aplikasi Flash Berbasis Android. Jurnal Pendidikan Fisika Dan Aplikasinya (JPFA), 3(1), 57-62.

Arsyad, A. (2013). Media pembelajaran; Edisi revisi. PT. Raja Grafindo Persada.

Borg, W.R. and Gall, M. . (2007). Educational Research: An Introduction. Longman, Inc.

Branch, R. M. (2009). Instructional Design: The ADDIE Approach. Springer. https://doi.org/DOI 10.1007/978-0-387-09506-6

Bucher, C. A. (1979). Foundations of Physical Education. Mosby; 8th edition.

Friesen, J. (2010). Learn Java for Android Depelovment. Apress.

Mahnun, N. (2012). Media Pembelajaran (Kajian terhadap Langkah-langkah

Pemilihan Media dan Implementasinya dalam Pembelajaran). Jurnal Pemikiran Islam, 37(1), 27-33.

Marhadini. (2017). Pengembangan Media Pembelajaran Berbasis Android pada Materi Gerak Parabola Untuk Siswa SMA. Unnes Physics Education Journal, 6(3), 39-43.

Marvin, H. (2018). Pengembangan Aplikasi Penjas-Pedia Pada Smartphone Berbasis Android Sebagai Media Pembelajaran Pendidikan Jasmani Untuk Kelas VII di Smpn 1 Bangkalan. SATRIA Journal Of "Sports Athleticism in Teaching and Recreation on Interdisciplinary Analysis, 1(1), 28-63.

Mohammadi, Neda., Ghorbani, V., \& Hamidi, F. (2011). Effects of e-learning on Language Learning. Procedia Computer Science, 3, 464-468.

Muhajir. (2017). Buku Guru: Pendidikan Jasmani, Olahraga, dan Kesehatan SMP/Mts Kelas VII (Rev. ed.). Pusat Kurikulum dan Perbukuan, Balitbang, Kemendikbud.

Mulyatiningsih, E. (2014). Metode Penelitian Terapan Bidang Pendidikan. CV Alfabeta.

Nurseto, I. dan S. (2020). Pengembangan mobile learning senam lantai DBL 
berbasis android untuk kelas VII SMP. Jurnal Pendidikan Jasmani Indonesia, 16(2), 132-144.

Okilanda, A., Dlis, F., Humaid, H., Putra, D. D., Arisman, A., \& Muslimin, M. (2021). Defense Warm-Up Exercise Material for 13-Age Athlete Using Video Technology in Covid-19 Era. International Journal of Human Movement and Sports Sciences, 9(4), 629-634. https://doi.org/10.13189/saj.2021.090404

Open Handset Alliance. (2012).

Overview, T. (2009). Tools Overview, Android Developers.

Riduwan. (2011). Skala Pengukuran Variabel-variabel Penelitian. Alfabeta.

Sharfina, Z., \& Santoso, H. B. (2016). An Indonesian adaptation of the System Usability Scale (SUS). 2016 International Conference on Advanced Computer Science and Information Systems, ICACSIS 2016, 145-148. https://doi.org/10.1109/ICACSIS.2016.7872776

Sugiyono. (2011). Metode Penelitian Kuantitatif, Kualitatif dan R\&D. Alfhabeta.

Titting, F., Hidayah, T., \& Pramono, H. (2017). Pengembangan Multimedia Pembelajaran Senam Lantai Berbasis Android Pada Pendidikan Jasmani Olahraga Dan Kesehatan di SMA. Journal of Physical Education and Sports, 5(2), 120-126. https://doi.org/https://doi.org/10.15294/jpes.v5i2.13448

Welch, C. (2013). "Before it took over smartphones, Android was originally destined for cameras."

Werner, P. H. (2012). Teaching Children Gymnastics. Peter H. Werner, Lori H. Williams, Tina J. Hal.

Wiswanti, C., \& Belaga, S. Y. (2020). Integrasi Nilai Keislaman Dalam Proses Pembelajaran Di Era Mooc (E-Learning) Melalui Strategi Pre-Post Rules. Jurnal Pendidikan Islam, 11(1), 86-99. https://doi.org/https://doi.org/10.22236/jpi.v11i1.5037 